\title{
不飽和土の三軸圧縮状態における降伏関数
}

\section{YIELD FUNCTION OF UNSATURATED SOIL UNDER TRIAXIAL COMPRESSION}

\author{
軽 部大蔵*·勝山潤一**・西海健二***・丹羽尚 人**** \\ By Daizo KARUBE, Jun'ichi KATSUYAMA, Kenji NISHIUMI and Naoto NIWA
}

\begin{abstract}
Unsaturated soil can be simulated to elasto-plastic material. Based on the test results of suction controlled triaxial test on compacted kaolin clay, theoretical initial yield function and subsequent loading function are induced. Then the theory is examined by stress-probe test. In this paper triaxial stress state is defined by three stress components, they are, effective average principal stress, $p=\sigma_{m}-u_{a}$, effective suction stress, $f(S)=\chi\left(u_{a}-u_{w}\right)$ at failure condition, and deviator stress, $q=\sigma_{1}-\sigma_{3}$, in which $u_{a}$ and $u_{w}$ are pore air and pore water pressure, respectively. Only one loading function similar to Original Cam Clay is obtained from the theory, on the other hand, results of stress-probe test indicate the presence of additional yield surface like failure surface besides one theoretically predicted.
\end{abstract}

Keywords : unsaturated soil, suction, yield function, triaxial test

\section{1. まえがき}

不飽和土に作用する応力成分は, 全応力, 間隙空気圧 および間隙水圧であるが, 不飽和土塊のひずみや破壊を 考察するためには,これらを「全応力-間隙空気圧」と「間 隙空気圧-間隙水圧 (=サクション)」の 2 項にま之める と都合がよいことが 1960 年代の初めには明らかにされ ていた ${ }^{1)}$. 以来 20 年間にわたる研究の系譜を, サクショ ンを直接に制御・測定する力学試験に基礎を置く研究に 限って概観すると, まずビショップの有効応力定義 ${ }^{1)} に$

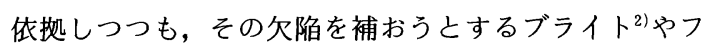
レルンド3) の研究活動と, ビショップへの批判として ジェニングスとバーランド4)およびコールマン ${ }^{5)}$ が行っ た提案に基礎を置くマトヤスとラダクリシナを的をじめ とする諸研究8),9) が併行していたが, 加えてこの 10 年来, 精密な三軸試験を行って新しい有効応力の定義を導く試 み(10) 12)がなされてきた。

一方, 飽和土の分野では, 弾塑性仮定に基づく構成方 程式が高い水準に達し, 普及・応用段階を迎えようとし

* 正会員 工博 神戸大学助教授 工学部土木工学科 （６57 神戸市灘区六甲台町）

** (株)リクルートRCS 科学システム部

*** 神戸大学大学院工学研究科修士課程

**** (株)建設技術研究所技術第 1 部
ている.その 1 つの応用として, 軽部らは, 締め固めた 不飽和カオリンを三軸試験して, 破壊応力に及ぼすダイ レイタンシーの影響や, ひずみの応力径路依存性を検討 し, 不飽和土の力学的特性が弾塑性仮定の適用性も含め て飽和土のそれの延長線上にあることを示唆し ${ }^{11)}$, また, 等方応力状態における降伏関数（あるいは負荷関数）を 提案した ${ }^{13), 14)}$. 同様にアロンソら ${ }^{15)}$ は既往の圧密試験結 果を収集・分析し, 定性的ではあるが, 3. で紹介する ように, より詳細な降伏線を提案した。 また彼らは, $K_{0}$ 圧密中の降伏を説明するための, せん断応力軸を含 む応力空間に仮想された降伏面を紹介した.これら 13) 15) は, いずれも不飽和土特有のコラプス現象を弾塑性挙動 の一部として説明できるものである. 続いて軽部 ${ }^{16)}$ はカ ムクレイモデル ${ }^{17)}$ にならって, 先の等方応力面上の降伏 線の上に立つ降伏面等を応力空間内に想定し, これと三 軸ストレスプローブ試験結果 ${ }^{18)}$ を比較した. 以上とは独 立に, 向後 ${ }^{19}$ は「等価間隙水圧」を導入して有効応力を 定義し，これを修正カムクレイ型の飽和土用構成式に適 用して塑性ポテンシャル関数を得た。

本論文の目的は, 著者の一部が加わった従来の諸論文 を含めて, これまで飽和土からの類推として直感的に提 案されてきた諸式を, 不飽和土塊が満たすべき理論関係 と矛盾しない形式に改め，それらを実験結果とつき合わ 
せて検討することにある，なお，本論文で提案する降伏 関数等に基ついて誘導される構成方程式については，紙 数の制約から続稿に譲っている.

〔記号の定義〕

$\sigma_{1}, \sigma_{2}=\sigma_{3}$ : 全応力表示の最大, 最小主応力.

$u_{a}, u_{w}$ : 間隙空気圧, 間隙水圧. 飽和状態で は形式上, $u_{a}=u_{w}$ としておく。

$p=\frac{\sigma_{1}+2 \sigma_{3}}{3}-u_{a}$ : 間隙空気圧を差し引いた平均主応 力.

$$
\begin{gathered}
q=\sigma_{1}-\sigma_{3}: \text { 主応力差. } \\
S=u_{a}-u_{w}: \text { サクション. }
\end{gathered}
$$

$f(S)$ :「サクション応力」と仮称. $S$ が塑 性ひずみに与える影響を等価の $p$ に換算する関数. カオリン粘土供試 体に対する実験式 ${ }^{20)}$ は,

$$
\begin{aligned}
f(S) & =\left[\sqrt{1+\frac{3 S}{98 \mathrm{kPa}}}-1\right] \times \frac{98 \mathrm{kPa}}{1.5} \\
w & : \text { 含水比. } \\
e & : \text { 間隙比. }
\end{aligned}
$$

$\lambda=0.434 C_{c}, k=0.434 C_{s}:$ 片自然対数紙上での圧縮 指数, 膨潤指数.

$\varepsilon_{1}, \varepsilon_{2}=\varepsilon_{3}:$ 最大, 最小主ひずみ. 主応力方向に 一致すると仮定.

$v:$ 体積ひずみ.

$\varepsilon=(2 / 3)\left(\varepsilon_{1}-\varepsilon_{3}\right):$ せん断ひずみ.

$M, M^{\prime}$ : せん断抵抗係数, ダイレイタンシー 補正したせん断抵抗係数（式（1） 参照).

$P=P(p, q, S)$ : 応力空間内の応力点.

$A=P_{A}(p=20, q=0, S=49 \mathrm{kPa}):$ ひず測定の原点

\section{2. サクションー定の三軸圧縮試験に対する負 荷曲線}

軽部ら ${ }^{11}$ は，本論文 5. の冒頭部に示された方法で力 オリン粘土供試体について排気・排水三軸圧縮試験を行 い, 次の破壊応力条件式を得た。

$$
q_{f}^{\prime}=M^{\prime}(p+f(S)) \text {. }
$$

ただし， $q_{s}^{\prime}$ は，破壊時の主応力差 $q_{s}$ に，次のダイレイ タンシー補正を施した值である。

$$
q_{f}^{\prime}=q_{s}+p\left(\frac{\Delta v}{\Delta \varepsilon}\right)_{s}
$$

また, $M^{\prime}$ は $q_{f}^{\prime} \sim p$ 座標に描いた破壊線（式 $\left.(1)\right)$ の $p$ 軸に対する傾きであり, $-f(S)$ は，その $p$ 軸切片で ある. したがって $f(S)$ は，破壊条件におけるサクショ ンの作用を等価の $p$ に換算する関数であり, 以下「茾 クション応力」と仮称する. 式 (1)，(2) より

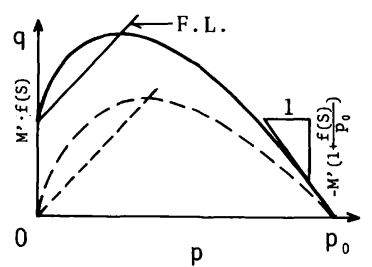

Fig. 1 Loading curves on suction constant plane.

$$
\left(\frac{\Delta v}{\Delta \varepsilon}\right)_{s}=M^{\prime} \frac{p+f(S)}{P}-\frac{q_{s}}{p}
$$

これとは別に，ロスコら ${ }^{17)}$ がカムクレイモデルを導い た方法にならって, 軸圧縮中の不飽和供試体のエネル ギーつり合い式を書くと,

$$
\begin{aligned}
& p \cdot d v+q \cdot d \varepsilon=M^{\prime}\{p+f(S)\} d \varepsilon+p \cdot d v^{e} \\
& \therefore \quad \frac{d v^{\rho}}{d \varepsilon}=M^{\prime} \frac{p+f(S)}{p}-\frac{q}{p}
\end{aligned}
$$

ただし $d v^{p}=d v-d v^{e}$

ここで, 先の式（3）は $p$ と $S$ を一定に保った場合で あるから， $\Delta v=\Delta v^{p}$ ，したがって理論式（4）は破壊 時において実験式 (3) に一致し,この限りで実証され たことになる。

さて，式（4）は暗墨に，せん断ひずみをすべて塑性 成分と仮定しているから，左辺は塑性ひずみ増分比であ る.ここで関連流動則を適用し， $S$ 一定面上の負荷曲 線の勾配を $(d q / d p)$ とすれば,

$$
(d q / d p)=-\left(d v^{\rho} / d \varepsilon\right)
$$

これを式（4）に代入すると,

$$
\frac{d q}{d p}-\frac{q}{p}=-M^{\prime} \frac{p+f(S)}{p}
$$

上式を, $q=0$ のとき $p=p_{0}$ として解くと, サクション 一定面上の負荷曲線の式が次のように得られる.

$$
\frac{q}{M^{\prime} p_{0}}=-\frac{p}{p_{0}} \log _{e}\left(\frac{p}{p_{0}}\right)+\frac{f(S)}{p_{0}}\left(1-\frac{p}{p_{0}}\right) \text {. }
$$

Fig. 1 の実線は上式を，また破線は，次のカムクレイモ デルの負荷曲線を表わしている.

$$
\frac{q}{M^{\prime} p_{0}}=-\frac{p}{p_{0}} \log _{e}\left(\frac{p}{p_{0}}\right) \text {. }
$$

ただし，カムクレイモデルでは， $M^{\prime}=M=(q / p)_{s}$.

\section{3. 等方応力状態における負荷曲線}

サクション $S$ を独立応力成分と考えると, 三軸圧縮 状態にある不飽和土の負荷関数は，3つの独立応力成分 $(p, S, q)$ で構成される三次元空間内の曲面として 定義される，しかし，サクションが不飽和土のひずみに 及ぼす影響の程度は土質によって大きな差があり，しか も同一土質であっても初期含水比等に影響されるので, サクション $S$ をそのまま応力軸とすると関数が複雑と なるおそれがある.これを避ける 1 つの方法として，S 
の代わりにサクション応力 $f(S)$ を用いると関数が単 純となることがわかれば，以後は $f(S)$ の性質を調べ ればよいことになる.

さて, 等方応力状態あるいは一次元圧縮状態にある飽 和土の降伏応力は, $e \sim \log p$ 線が曲線から直線に移行 する点として定義されている，言い換えれば，飽和土は 弾塑性状態 (正規圧密域) では次の式に従うことが前提 とされているわけである.

$e-e_{1}=-C_{c}\left(\log _{10} p-\log _{10} p_{1}\right)$

ただし， $p=p_{1}$ のとき, $e=e_{1}$ とする.

上式を $p$ で微分すると, 次の式に到達する.

$$
-\left(\frac{d p}{d e}\right)=\left(2.3 / C_{c}\right) p
$$

したがって，飽和土は弾塑性状態においては， $p$ に比例 して硬くなることになる，一方，不飽和土の場合，弾塑 性状態における硬さは $[p+f(S)]$ に比例するであろ う11).すなわち

$$
-\frac{d e}{d p}=\frac{0.434 C_{c}}{p+f(S)}
$$

したがって，圧密中 $S$ が一定に保たれる場合は，

$$
e=e_{1}-C_{c} \log _{10} \frac{p+f\left(S_{1}\right)}{p_{1}+f\left(S_{1}\right)}
$$

ただし， $p=p_{1}$ のとき, $S=S_{1}$ および $e=e_{1}$ とする.

Fig. 2 は, 文献 11) の Table 1 および勝山ら ${ }^{20)}$ の等方圧 密中の $e \sim \log _{10}[p+f(S)]$ 関係を示している. $S$ は実線 部分で一定に保たれたが，図より $[p+f(S)]$ が大きくな ると直線関係となることが，测定点数の多い供試体から 確認できる．ところが同じデー夕を $\log _{10} p$ に対してプ ロットすると，直線区間が短くなることがわかった．ま た既往の文献 ${ }^{6) .71 .9)}$ においても， $e \sim \log _{10} p$ 関係の直線部 は $S$ が小さい場合を除いて，ごく短いか無い.

式 (11) が不飽和土の弾塑性状態を表わすとすれば, 不飽和土の降伏応力は, $e \sim \log [p+f(S)]$ 図上で，飽和
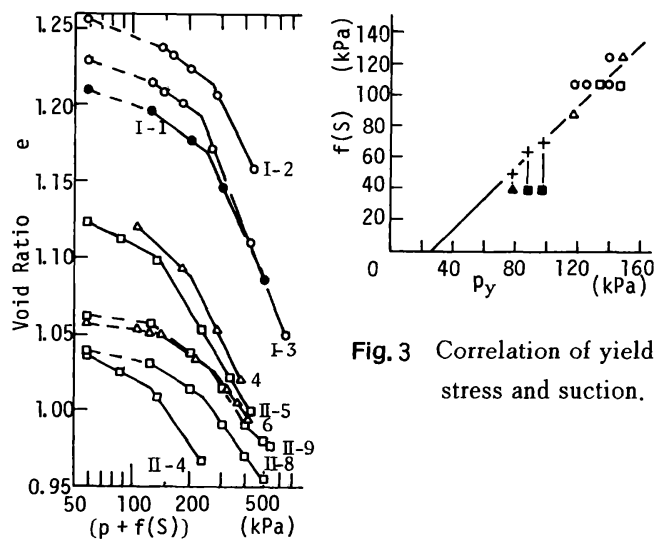

Fig. 3 Correlation of yield stress and suction.
土と同様にカサグランデ法等で決定できるはずである.

しかし，Fig. 2 の場合は測定点数が少ないことから同法 の適用は困難であるため，2 本の直線で近似し，折点の 応力を $\left[p_{y}+f(S)\right]$ とみなすこととした.Fig. 3 において， 十印以外の点は $f(S)$ と $p_{y}$ の関係を表わしている. 図 において注意すべきは, 縦軸の $f(S)$ は圧密試験中の ものであり, いわば「先行サクション応力」ではないこ とである. 実際，最初に供試体を応力状態 $\mathrm{A}(p=20$, $S=49 \mathrm{kPa})$ に置いたとき，ほとんどが吸水したから， 供試体作製直後の初期サクション $S_{i}$ は $49 \mathrm{kPa}$ を超え ていたと思われる.この $S_{i}$ を, 圧密中のサクション応 力が $f(S)=39 \mathrm{kPa}$ (黒印) の 3 個の供試体について推 定したところ，図中の十印を得た。十印と他の白印を総 合する之, 降伏応力 $p_{y}$ は, 供試体がその時点までに受 けた最大サクション応力 $f(S)$ に比例的に増大するこ とがわかる.なお， $S_{i}$ の推定は，各供試体について $\Delta S=S_{i}-49 \mathrm{kPa}$ とおいて, 別に文献 11), Fig. 7 から 得られた実験式, $\Delta S=\left\{(0.12 e-0.11)^{-1}\right\} \Delta w$ を求めて おき，各供試体の吸水量 $\Delta w$ を代入して行った。

供試体の初期状態をさらに検討するために, 三軸試験 とは別に Fig. 4 に示す標準圧密試験を，気乾，飽和，不 飽和カオリン試料について行った。図を用いて，三軸試 験用供試体が供試体作製時に受けた応力 $p_{y}$ を次のよう に見積った。まず， $e$ 軸上に三軸供試体の平均初期間隙 比 1.23 をとり，ここから不飽和試料の除荷曲線に平行 線を引くと, 不飽和圧密曲線と $e=1.17$ で交わるから, この間隙比を飽和試料の圧密曲線上にとると, $p=130$ $\mathrm{kPa}$ に対応する. 一次元圧縮状態と Fig. 3 の等方応力 状態を比較するのは困難であるが，ダイレイタンシーを 無視したうえで $K_{0}=0.5$ と仮定すれば, $130 \mathrm{kPa}$ の一次

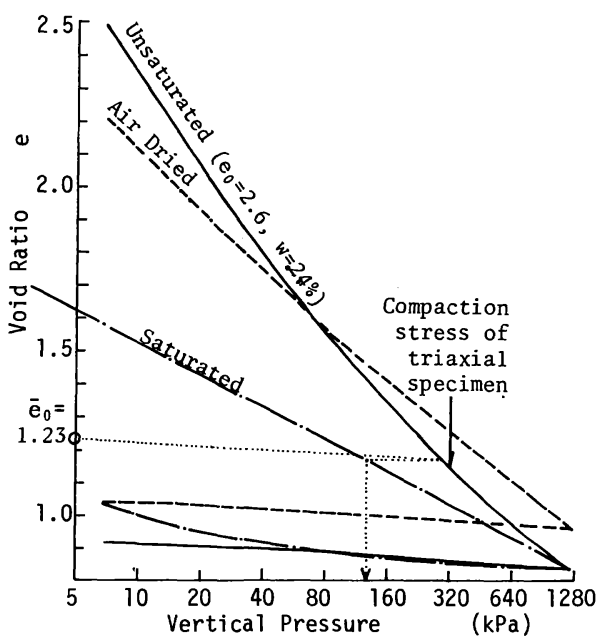

Fig. 4 Influence of degree of saturation on consolidation curves.

Fig. 2 Consolidation curves. 
元圧縮応力は $87 \mathrm{kPa}$ の等方応力に相当する.すなわち, 三軸供試体の突固め力は等価圧密応力にして $87 \mathrm{kPa}$ 程 度と推定されたが, この值は偶然か, Fig. 3 の初期降伏 応力（黒印）に一致する.また, Fig. 4 中の実線矢印は 供試体の締固め応力を表わしているが，この応力も締固 めに有効に作用したことがわかる.

等方応力条件下の降伏関数を考察するにあたっては， $f(S)$ が土の骨格構造を強化するのに対して, $p$ は逆に 骨格を圧縮することに注意する必要がある.そのために， ここでは次のように応力面を 2 分して考察する (Fig.5 参照). まず, $p \leqq f(S)$ の領域では, サクション応力 $f(S)$ が支配的と考え， $f(S)$ のみで降伏が起こるかを検討す る. ヨンら ${ }^{211}$ は，カオリン粘土等をスラリー状からサク ションのみで圧密して， $S=0.1 \sim 100 \mathrm{kPa}$ の区間で大 きな非可逆圧縮を認めた。 また，アロンソら ${ }^{15}$ の引用に よれば, Chu と Mou (3 IC-Expansive Soils) は, $S_{i}$ $>300 \mathrm{kPa}$ の膨張性粘土のサクションをいったんゼロに したところ，大きな非可逆膨張を起こした．アロンソら は，これらの現象を説明するために，サクション増大・ 減少両方向にそれぞれ $S=$ 一定という降伏線を設定し た.しかし，前者のようにサクション圧密をスラリーか ら始めると, サクションがかなりの值に達するまで供試 体内部は飽和状態にとどまるものであり（つまりサク ションは供試体表面にしか現われない), また後者の膨 張性粘土はむしろ特殊土であって, 結果の一般性に問題 があろう。

一方, 文献 11）の Fig. 9 によれば, $p$ を一定に保ち, $S$ を $49 \mathrm{kPa}$ から供試体の推定初期サクションをはるか に超える $198 \mathrm{kPa}$ までの範囲で増減させた場合の, 体 積ひずみ増分/サクション増分比 $(\Delta v / \Delta S)$ は，大き い $p$ のもとで $S$ を減少させてコラプス履歴をつくらな い限り, 載荷時と除荷時で大きな差は認められず, した がって降伏は起こっていないと考えられる．結局，サク ションのみによって降伏が起こるかについては文献の結 論は一致しないが，この原因は試料土の構造の差による と思われる．以下では，文献11）で用いられたような, 最適含水比付近の, したがって間隙水も間隙空気もとも に連続している状態にある場合を中心に議論を進めるこ
ととする.

次に, $p>f(S)$ の領域における降伏線を考察する. 土の初期応力を $P_{i}\left(p_{i}, S_{i}\right)$ とすると, $p_{i}$ と $f\left(S_{i}\right)$ の大 小関係により降伏線は異なったものとなるであろう.

a) $p_{i} \leqq f\left(S_{i}\right)$ の場合 サクションの值が締固め直 後より低下しても土の骨格構造は残留するとすれば，降 伏線の式は Fig. 5 に示すように

$$
p=p_{y}=f\left(S_{i}\right)
$$

一方, サクションの低下により骨格構造が乱れるとする 亡,

$$
p=f\left(S_{i}\right) \cdot(1-b)+f(S) \cdot b
$$

ただし， $b$ はゼ口と 1 の間に定義される新たな実験定数 であり， $b=0$ のときは, 式 $(12 \cdot \mathrm{b})$ は式 $(12 \cdot \mathrm{a})$ に一 致する.

b) $p_{i}>f\left(S_{i}\right)$ の場合

$p=p_{y}$

ただし, 式中の $p_{y}$ は, 初期サクション $S_{i}$ を超えない 一定サクションのもとで $p$ を増加させる圧密試験を行 い，直接に実測しなければならない (Fig.2，3参照). 以上の式 $(12 \cdot \mathrm{a}) \sim(13)$ の成立範囲は, $S \leqq S_{i}$ として おく.

土に作用する応力 $(p, f(S))$ が降伏線を超えて増加 すると土は弾塑性状態となるが, この場合, 塑性体積ひ ずみは応力径路によらず応力状態で決まることが実験的 に確かめられているから ${ }^{6), 8)}$, 式 (10) より

$$
\frac{\partial v^{p}}{\partial p}=m_{v}-m_{v}^{e}=\frac{\lambda-x}{1+e_{A}} \frac{1}{p+f(S)}
$$

ただし, $m_{v}^{e}$ は弾性体積圧縮係数, $\lambda$ と $x$ は圧縮, 膨潤 指数, $e_{A}$ はひずみ測定原点における間隙比である.

上式を積分し，降伏線上で $v^{p}=0$ とおけば，式 $(12 \cdot a)$ および式 (13) に対応する塑性体積ひずみは次式で与え られる。

$$
v^{\rho}=\frac{\lambda-x}{1+e_{A}} \log _{e} \frac{p+f(S)}{p_{y}+f(S)}
$$

また, 式 $(12 \cdot b)$ に対応する塑性体積ひずみは次式で 与えられる.

$$
v^{p}=\frac{\lambda-\varkappa}{1+e_{A}} \log _{e} \frac{p+f(S)}{(1-b) f\left(S_{i}\right)+(1+b) f(S)} \cdots
$$
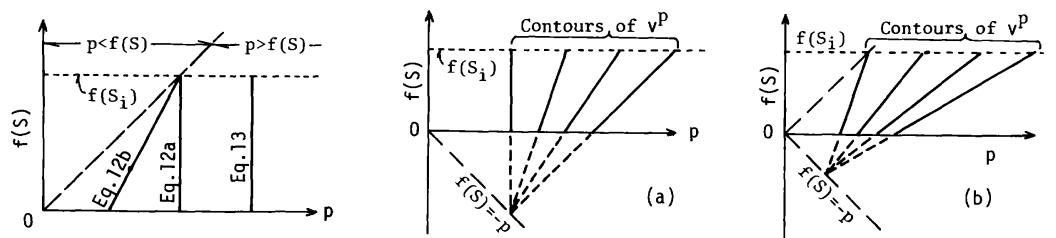

Fig. 5 Hypothetic yield curves.
Fig. 6 Characteristics of plastic volumetric strain on $p \sim f(S)$

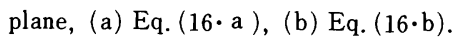

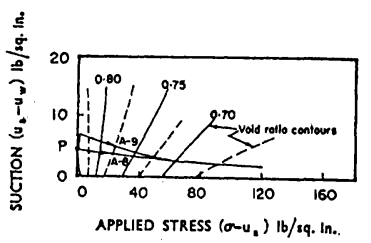

Fig. 7 Contours of volumetric strain ${ }^{6)}$. 
ここで，負荷曲線は等塑性ひずみ線に一致するとすれば

$$
C=\left(\frac{1+e_{A}}{\lambda-x}\right) v^{p}=\text { const. }
$$

とおいて, 式 $(15 \cdot a),(15 \cdot b)$ を書き直すことにより, 次のように表わされる.

$$
\begin{aligned}
& p=\{\exp (C)-1\} f(S)+\exp (C) p_{y} \cdots \cdots \cdots \cdots \cdots(16 \\
& p=\{\exp (C)(1+b)-1\} f(S)+\exp (C)(1-b) f\left(S_{i}\right)
\end{aligned}
$$

これらの負荷曲線（等塑性ひずみ線）の特徵は, Fig. 6 に示すように, 直線 $p=-f(S)$ と降伏線の交点 を通ることである．Fig.7はマトヤスら ひずみ線であるが, Fig.6に類似している.

最後に, 弾塑性状態にある土のサクションが先行サク ションを超えて増大する場合については，降伏線が塑性 ひずみを伴わずに $p$ 方向に平行移動すると仮定してお

く (Fig. 8). すなわち,

$$
\begin{aligned}
p= & \left\{\exp \left(C_{l}\right)-1\right\} f(S)+\exp \left(C_{l}\right) \\
& \times\left\{p_{y}-f\left(S_{i}\right)+f\left(S^{\prime}\right)\right\} \cdots \cdots \cdots
\end{aligned}
$$

ただし， $C_{l}$ は， $\left(v^{p}\right)_{l}$ をサクションが増加の途上で $S_{i}$ に 達したときの塑性ひずみとするとき，次の式で与えられ る.

$$
C_{l}=\left(\frac{1+e_{A}}{\lambda-\varkappa}\right)\left(v^{p}\right)_{l}
$$

また, $S^{\prime}$ は, 増大後の $S\left(>S_{i}\right)$.

式 (17・a) の適用例として, Fig.3において+印で表わ した初期サクション $S_{i}$ より大きなサクションを負荷さ れた供試体の理論降伏応力を求めてみると，これらの応

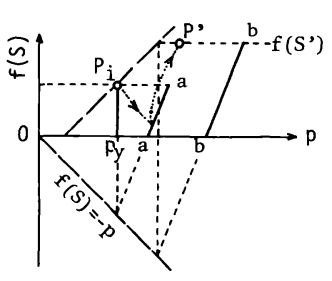

Fig. 8 Shift of loading curve.

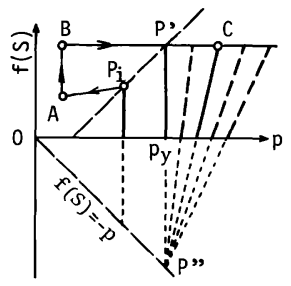

Fig. 9 Analysis of Fig. 3 using Fig. 8.

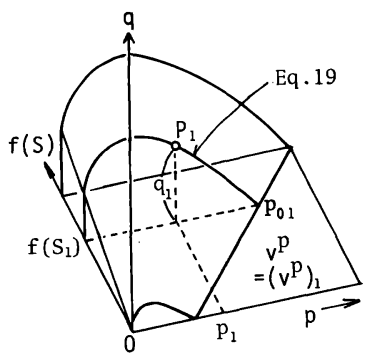

Fig. 10 Loading surface through stress point $P_{1}$.
力径路は Fig. 9 の $P_{i} \rightarrow \mathrm{A} \rightarrow \mathrm{B} \rightarrow \mathrm{C}$ であるから, 降伏応力 は, Fig. 3 の十印を通る $45^{\circ}$ 線と圧密径路の交点 $P^{\prime}$ と なる. 実測降伏点 (白抜印) 群は $45^{\circ}$ 線付近に分布して おり，式（17）を支持している，なお，新しい降伏線以 後に発生する塑性ひずみの式は,

$$
\left(v^{D}\right)^{\prime}=\frac{\lambda-\varkappa}{1+e_{A}} \log _{e} \frac{p+f(S)}{p_{y}-f\left(S_{i}\right)+f\left(S^{\prime}\right)+f(S)} \cdots(18 \cdot \mathrm{a})
$$

となり, 負荷曲線（等塑性ひずみ線）は Fig. 9 の点 $P^{\prime \prime}$ を通る直線群となる。

\section{4. 空間負荷曲面}

不飽和土が等方硬化材料であれば, 応力空間（ $p$, $f(S), q)$ 内の負荷曲面の式は，等方応力面上の負荷曲 線式 (16) の $p$ を $p_{0}$ と書き改め, $f(S)$ 一定面上の負 荷曲線式（6）に代入すれば得られる.

載荷応力径路が応力空間内の任意の点 $P_{1}\left(p_{1}, f\left(S_{1}\right)\right.$, $q_{1}$ ) に達したとき， $P_{1}$ が形成する負荷曲面は Fig. 10 を 参照して，次のように決定できる．まず式 $(6)$ に点 $P_{1}$ の座標を代入すると次式となる.

$$
\frac{q_{1}}{M^{\prime}}=-p_{1} \log _{e}\left(\frac{p_{1}}{p_{01}}\right)+f\left(S_{1}\right)\left(1-\frac{p_{1}}{p_{01}}\right) \text {. }
$$

ただし， $p_{01}$ は等方応力面上の点である．次に，上式を $p_{01}$ について解き，式（15）を式（16）を用いて書き直 しておいた式に， $f\left(S_{1}\right)$ とともに代入する;

$$
C_{1}=\left(\frac{1+e_{A}}{\lambda-x}\right)\left(v^{p}\right)_{1}=\log _{e} \frac{p_{01}+f\left(S_{1}\right)}{p_{y}+f\left(S_{1}\right)}
$$

この $C_{1}$ を元の空間負荷曲面の式に代入すると, 最終的 に $P_{1}$ を通る負荷曲面の式が次のように求められる.

$$
\frac{q}{M^{\prime}}=-p \log _{e}\left(\frac{p}{p_{0}}\right)+f(S)\left(1-\frac{p}{p_{0}}\right) \cdots \cdots \cdots \cdots(6)_{\text {bis }}
$$

ただし， $p_{0}=\left\{\exp \left(C_{1}\right)-1\right\} f(S)+\exp \left(C_{1}\right) p_{y}$

\section{5. ストレスプローブ試験}

理論的に予測された負荷曲面（関数）を実験的に検討 するために, Table 1 に示す 6 シリーズのストレスプ ローブ試験を行った．基本的な試験方法は文献 11）・の シリーズ II と同様であるが，その概略は，粉末カオリン の含水量を調整して, 内径 $35 \mathrm{~mm}$ のモールドに入れ, カリフォルニア・ミニチュアコンパクターで締め固めて 高さ $80 \mathrm{~mm}$ の供試体を得, これを応力点 $\mathrm{A}(p=20, S$ $=49 \mathrm{kPa})$ から 1 段階 8 時間の段階応力制御法で三軸 圧縮試験するものである.

\section{（1）等方応力面上の弾性域}

等方応力履歴による弾性域の形成をシリーズ【Iの $2 つ$ の供試体で検討した．与えた応力履歴は Fig.11(a) の $\mathrm{A} \rightarrow \mathrm{B} \rightarrow \mathrm{C}$ であり, 続いてストレスプローブ $\mathrm{C} \rightarrow 1 \rightarrow \mathrm{C} \rightarrow$ $2 \rightarrow C \rightarrow 3 \rightarrow C$ を与えた. Fig.11(b) 上において, 点 $C$ 
と任意の点の距離を, 次の $\Delta \sigma$ で定義すると, $\Delta \sigma=\sqrt{(\Delta p)^{2}+(\Delta f(S))^{2}}$

ただし, $\Delta p=p-(p)_{c}, \Delta f(S)=f(S)-f(S)_{c}$.

Fig. 11(c), (d) に示すように, C $\rightarrow 1$ に伴う間隙比変 化率は, 先の載荷径路 $\mathrm{B} \rightarrow \mathrm{C}$ のそれに比べて非常に小 さく, 弾性域にあるとみられる. 続く $\mathrm{C} \rightarrow 2$ は, 変化成 分 $\Delta p=-104 \mathrm{kPa}$ と $\Delta f(S)=23 \mathrm{kPa}$ に分解できる.こ れらに対応する間隙比変化量 $\Delta e_{p}, \Delta e_{s}$ を，それぞれ $\mathrm{C} \rightarrow 1$ と $\mathrm{C} \rightarrow 3$ から読み取って加え合わせると，

$\Delta e_{p}+\Delta e_{s}=0.004-0.002=0.002$

この值は, $\mathrm{C} \rightarrow 2$ の実測間隙比変化量に等しい. 以上より, 全プローブは弾性域にあると結論でき，3．の負荷曲線 に関する理論に矛盾しないことがわかる。なお，Fig. 11 (c) 中の「gap」部分は, 軸変位計の接点が動いたこと による誤差である.

\section{（2）等方応力履歴と後続のせん断特性の関係}

シリーズI'と，Fig.12 に示すように，点 A から $\mathrm{B}\left(\mathrm{B}^{\prime}\right)$ あるいは $\mathrm{D}\left(\mathrm{D}^{\prime}\right)$ を経て $\mathrm{C}\left(\mathrm{C}^{\prime}\right)$ まで圧密され，

Table 1 Conditions of stress-probe test.

\begin{tabular}{|c|c|c|c|c|c|c|}
\hline \multirow{2}{*}{\begin{tabular}{|l|} 
Test \\
Series
\end{tabular}} & \multirow{2}{*}{$\begin{array}{l}\text { Specimen } \\
\text { Number }\end{array}$} & \multicolumn{3}{|c|}{ Molded State } & \multirow{2}{*}{ Stress Path } & \multirow{2}{*}{$\begin{array}{l}4 \dot{0} \\
\propto \\
\end{array}$} \\
\hline & & $\mathrm{e}$ & $w(\%)$ & $\mathrm{S}_{\mathrm{r}}(\%)$ & & \\
\hline II & $\begin{array}{l}1 \\
2 \\
3\end{array}$ & $\begin{array}{l}1.163 \\
1.121 \\
1.277\end{array}$ & \begin{tabular}{|l|}
26.44 \\
25.45 \\
23.90
\end{tabular} & $\begin{array}{l}61.38 \\
61.31 \\
50.72\end{array}$ & $\begin{array}{l}A B^{\prime} C^{\prime}+A x \text {. Comp } \\
A D^{\prime} C^{\prime} \rightarrow A x \text {. Comp } \\
A B^{\prime} C^{\prime} E^{\prime} C \rightarrow A x . C .\end{array}$ & \multirow[b]{2}{*}{ ir } \\
\hline III & $\begin{array}{l}4 \\
5 \\
6 \\
7 \\
\end{array}$ & $\begin{array}{l}1.261 \\
1.292 \\
1.235 \\
1.257\end{array}$ & \begin{tabular}{|l|}
26.51 \\
25.86 \\
24.75 \\
25.80 \\
\end{tabular} & $\begin{array}{l}59.99 \\
54.25 \\
54.29 \\
55.62\end{array}$ & $\begin{array}{l}A B C \rightarrow A x . \text { Comp. } \\
A D C \rightarrow A x . \text { Comp. } \\
A B C E C \rightarrow A x \text {. Comp } \\
A B C F C \rightarrow A x \text {. Comp. }\end{array}$ & \\
\hline IV & $\begin{array}{r}8 \\
9 \\
10 \\
14 \\
\end{array}$ & $\begin{array}{l}1.238 \\
1.159 \\
1.315 \\
1.267 \\
\end{array}$ & $\begin{array}{l}25.93 \\
26.11 \\
28.21 \\
26.69 \\
\end{array}$ & $\begin{array}{l}56.77 \\
61.03 \\
58.13 \\
57.11 \\
\end{array}$ & $\left\{\begin{aligned} A B C & \begin{array}{l}\Delta p>0 \\
\mathrm{JIJ} J\end{array} \\
& \Delta S<0 \\
& \Delta \mathrm{Sp}<0 \\
\Delta \mathrm{p}, \Delta S<0 & \end{aligned}\right.$ & \multirow{3}{*}{$\frac{\circ}{\dot{\sigma}}$} \\
\hline v & $\begin{array}{c}8, \\
9 \\
10 \\
14 \\
\end{array}$ & $\begin{array}{l}1.282 \\
1.259 \\
1.281 \\
1.235\end{array}$ & $\begin{array}{l}26.42 \\
26.41 \\
26.40 \\
25.86 \\
\end{array}$ & \begin{tabular}{|l|}
55.84 \\
56.85 \\
55.86 \\
56.72 \\
\end{tabular} & 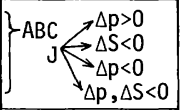 & \\
\hline VI & $\begin{array}{l}11 \\
12 \\
13\end{array}$ & $\begin{array}{l}1.254 \\
1.270 \\
1.257\end{array}$ & $\begin{array}{l}24.42 \\
23.67 \\
25.69\end{array}$ & $\left|\begin{array}{l}52.76 \\
50.51 \\
55.39\end{array}\right|$ & 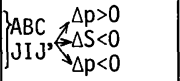 & \\
\hline VII & $\begin{array}{l}7 \\
8\end{array}$ & $\begin{array}{l}1.136 \\
1.116\end{array}$ & $\begin{array}{l}25.21 \\
25.90\end{array}$ & $\begin{array}{l}59.91 \\
62.65\end{array} \mid$ & 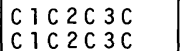 & .ं் \\
\hline
\end{tabular}
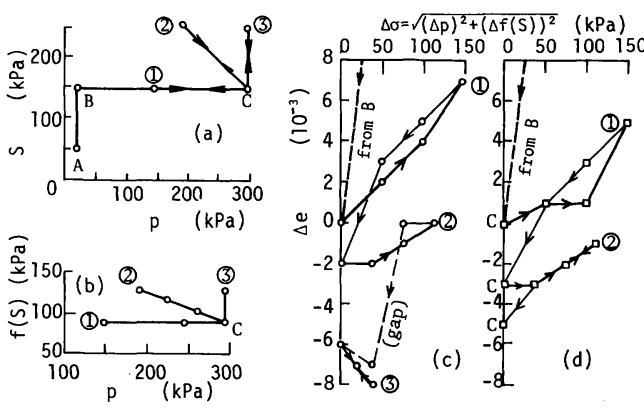

Fig. 11 Stress-probe test of series VII in elastic zone, (a), (b) stress paths tested, (c) void ratio change of specimen 7 , and (d) specimen 8 .
さらに一部は付加的載荷を受けた．Fig. 14，15 は，そ れに続く軸圧縮過程を示しており, 図中の矢印は Fig. 13 に示した各供試体の軸圧縮開始時における負荷 曲線が軸圧縮径路を横切る点を示している．矢印が右に 寄っているものほど初期部分の発生ひずみが小さいこと がわかり (5 7 は逆転), 等方応力履歴により負荷曲 面が三次元空間に広がるという理論が裏付けられた。

\section{（3） せん断履歴に伴う負荷曲面}

シリーズN $\mathrm{N}$, 圧密 $\mathrm{A} \rightarrow \mathrm{B} \rightarrow \mathrm{C}$ の後, Fig. 16(a) 中の $\mathrm{C} \rightarrow \mathrm{I} \rightarrow \mathrm{J}$ と載荷除荷され, 最後に Fig. 16(b)，（c) に示 す 4 つの径路 $8 ， 9 ， 10 ， 14$ をたよ゙った．各図中の実線 曲線は，点Iにおける負荷曲線である．Fig. 17～20 中 の実線曲線は, 点 $\mathrm{J}$ 以後のひずみを表わし, 曲線上の矢 印は径路と理論負荷曲線の交点を表わしている.しかし，

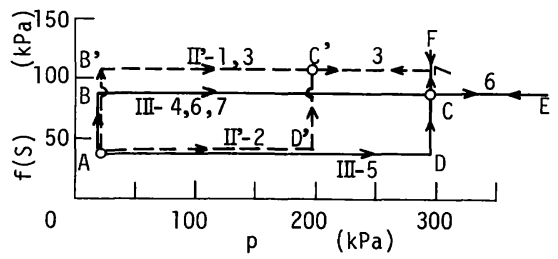

Fig. 12 Stress paths prior to axial compression.

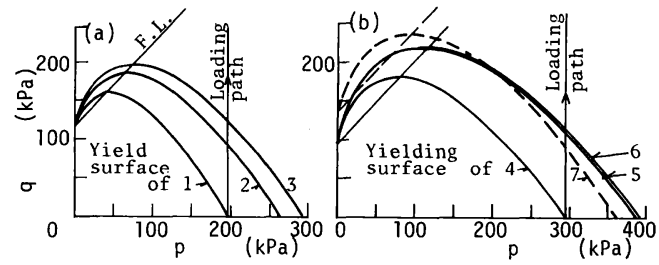

Fig. 13 Loading surfaces which each specimen had at point $\mathrm{C}$.
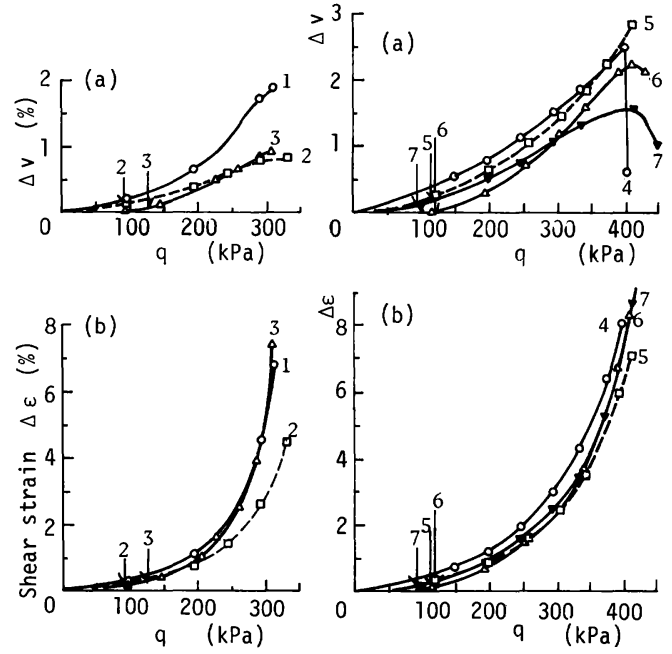

Fig. 14 Strains of Series II'. Fig. 15 Strains of Series III 
曲線は必ずしも急曲点などの特徵点をもっていないの で, 客観的に降伏点を決定するために, 付加シリーズ $\mathrm{V}$ を行った.このシリーズの応力径路はIまで行かず, J から直ちに Fig. 16(b)，(c) 中の 4 つの径路に入る.こ の場合点 Jにおける負荷曲線は各図中の破線曲線となる から，10'以外は J から弾塑性域を進行する.Jからの ひずみは Fig. 17〜20 中の破線で示されているが，これ らの初期勾配は実線のそれより明らかに小さい，そこで 実線の勾配が破線の初期勾配まで低下する点にメ印を付 け，「実測降伏点」と定義した。

一方，これらとは別にシリーズVは，いったん点 I ま で載荷してから点 J'まで除荷した後, Fig. 16(a)，(d) に点線で示す鉤形の径路をとらせた．Fig. 21 は，この 最後の $q$ 増加過程を示している. 当初の直線関係が崩 れる点を実測降伏点とした。

Table 2 と Fig. 22 は，シリーズ $\mathrm{N} \sim V$ 的ら得られた 全降伏点を示している。これらは理論負荷曲面とおおむ ね対応しているようであるが，供試体 10 および 13 の付 近には理論曲面がない，そこで次のいわば摩擦型の負荷 曲面を追加することとした。

$$
q=M^{\prime} \cdot f(S)+\frac{q_{1}-M^{\prime} \cdot f\left(S_{1}\right)}{p_{1}} \cdot p
$$

ただし，添字 1 は，点 Iにおける各成分の值を表わし， 式の形状は Fig. 22 中に太い破線で示されている.

\section{6. まとめ}

不飽和土の降伏関数と負荷関数を応力空間 $(p, f(S)$,
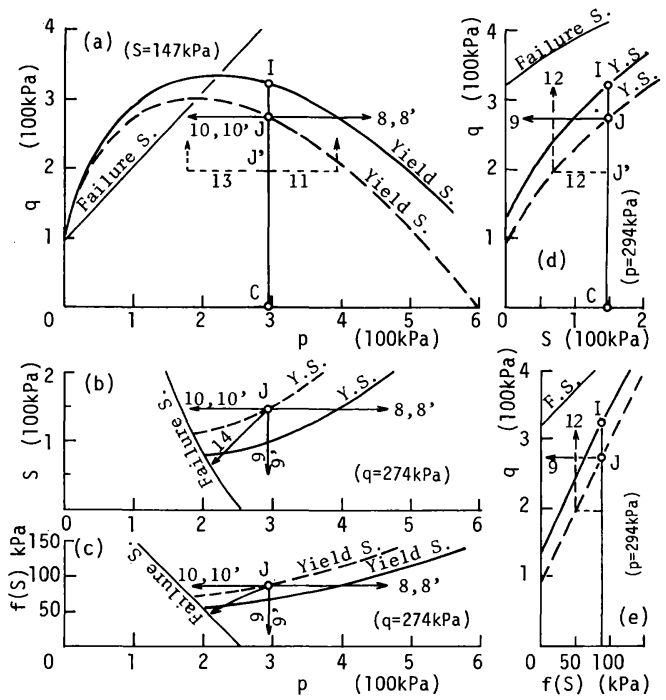

Fig. 16 Stress probes of Series IV-VI with relating theoretical loading surfaces through point I or J, (a) on $S=147$ $\mathrm{kPa}$, (b), (c) $q=274 \mathrm{kPa}$ and (d), (e) $p=294 \mathrm{kPa}$ plane. q）内で理論的・実験的に調べた. その結果，カムクレ イ型の負荷関数に加えて摩擦型の負荷関数が必要とわ かった．また，不飽和土の塑性体積ひずみ式を誘導した. さらに, 不飽和土の力学特性はサクション応力 $f(S)$ を用いると簡潔に表わせることがわかった。

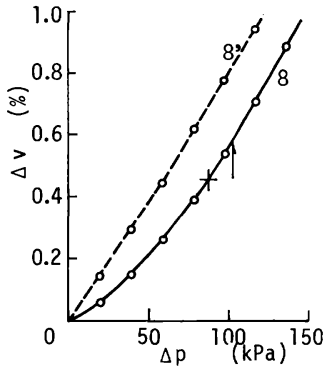

Fig. 17 Volumetric strains of specimen 8 and $8^{\prime}$ of series IV and V.
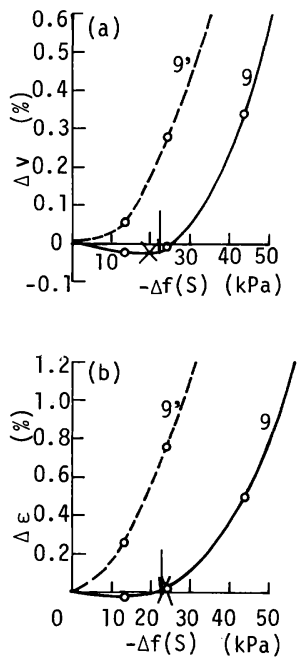

Fig. 19 (a) Volumetric and (b) shear strains of specimen 9 and $9^{\prime}$.

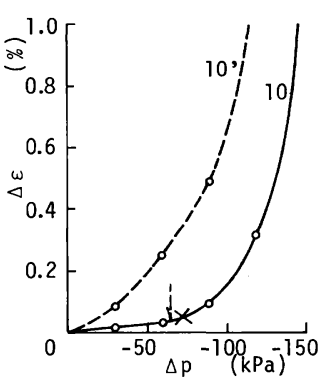

Fig. 18 Shear strains of specimen 10 and $10^{\prime}$ of series IV and $\mathrm{V}$.
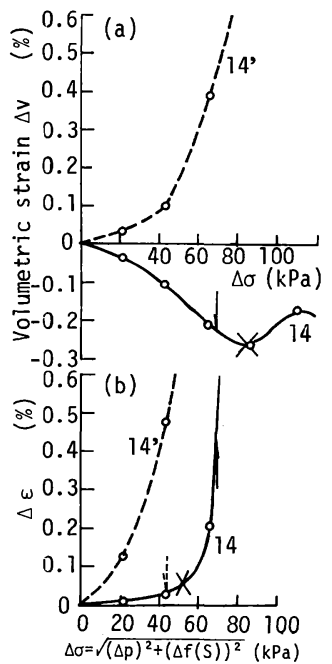

Fig. 20 (a) Volumetric and (b) shear strains of specimen 14 and $14^{\prime}$
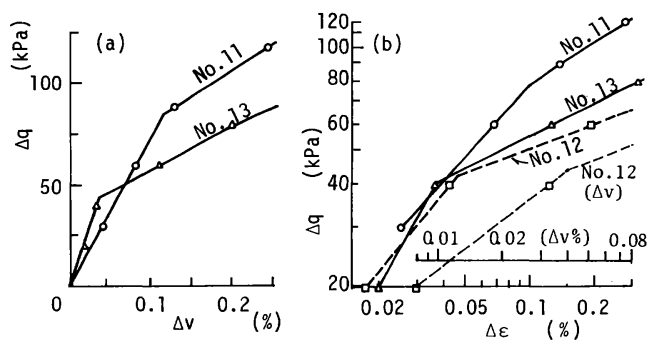

Fig. 21 Yield points appeared in stress-strain plots of specimen 11,12 and 13 of series VI. 
Table 2 Yield stresses induced by preceeding axial loading.

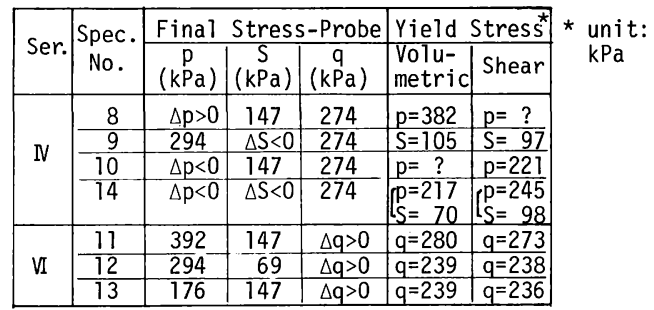
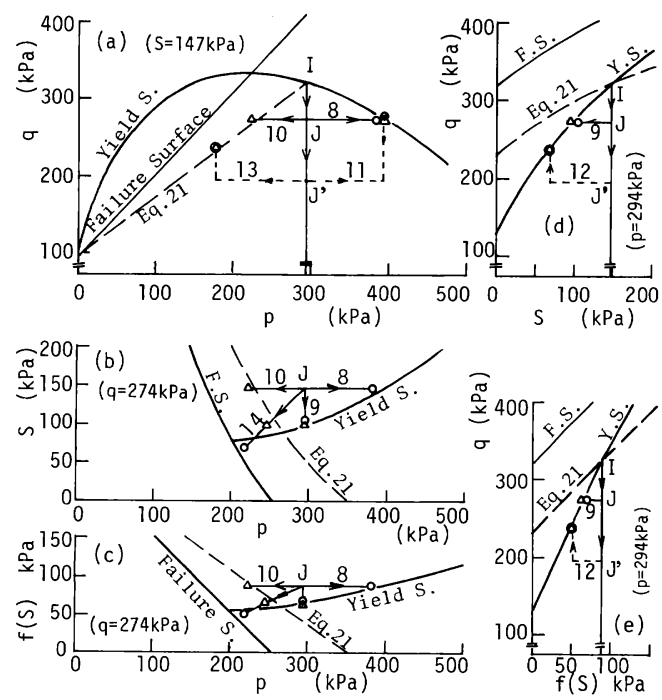

Fig. 22 Experimental yield points with relating theoretical loading surfaces;round mark and triangular mark denote volumetric and shear yield point, respectively.

本研究は, 神戸大学名誉教授 谷本喜一氏のご指導と 神戸大学 田中泰雄氏をはじめとする多くの方々のご助 言のもとで, 文部省科学研究費の補助 (一般 (B)) を 受けて行われたことを記し，深謝を表する.

1) Bishop, A.W. et al. : Factors controlling the strength of partly saturated cohesive soils, Proc. ASCE Colorado Conf., pp. 503 532, June, 1960.

2) Blight, G.E. : Effective stress evaluation for unsaturated soils, Proc. ASCE, Vol. 93, SM 2, pp. 125 148, 1967.

3) Fredlund, D. G. : Soil mechanics principles that embrace unsaturated soils, Proc. 11 th IC-SMFE, Vol. 2, pp. 465 472, Aug., 1975.

4) Jennings, J. E. and Burland, J. B. : Limitation to use of effective stress in partly saturated soils, Geotechnique, Vol. 12, pp. 125 144, 1962.

5) Coleman, D. J. : Correspondence, Geotechnique, Vol. 12, pp. 348 350, 1962.

6) Matyas, E.L. and Radhakrishina, H.S. : Volume change characteristics of partially saturated soils, Geotechnique, Vol.18, pp. 432 448, 1968.

7) Aichson, G. D. and Woodburm, J. A. : Soil suction in foundation design, Proc. 7 th IC-SMFE, Vol.2, pp. 1 $\sim 8,1969$.

8) Barden, L., Madedor, A. O. and Sides, G. R. : Volume change characteristics of unsaturated clay, Proc. ASCE, Vol. 95, SM 1, pp. 33 55, 1969.

9) Karube, D. : Effect of suction on soil behaviour, Proc. 7th ARC-SMFE, Vol. 1, pp. $30 \sim 35$, Aug., 1983.

10) Kawakami, H. and Abe, H. : Volume change characteristics and collapse in unsaturated soils during triaxial test, Proc. 5 th ARC-SMFE, Vol.1, pp. 111 116,1975 .

11）軽部大蔵・加藤正司・勝山潤一：不飽和カオリンの有効 応力と力学定数, 土木学会論文集, No. 370, pp. 179 188, 1986.

12）宇野尚雄・筧 正人・太田丈晴 : 不飽和砂質土の 3 軸試 験における状態量の計測, 不飽和土の工学的性質研究の 現状シンポジウム論文集, pp. 17〜22, Dec., 1987.

13) Karube, D. : Basic stress-strain relations of unsaturated soil, Proc. 8 th ARC-SMFE, Vol.1, pp. 17 20, July, 1987.

14) Karube, D. : New concept of effective stress in unsaturated soil and its proving test, ASTM, STP 977, pp. 539 —552, 1988.

15) Alonso, E. E., Gens, A. and Hight, D. : General report of Session 5, Preprint of 9 th ERC-SMFE, Aug., 1987.

16）軽部大蔵：不飽和土の構成式, 不飽和土の工学的性質研 究の現状シンポジウム論文集, pp. 59〜68, Dec. , 1987.

17) Roscoe, K. H., Schofield, A. N. and Thurairajah, A. : Yielding of clays in states wetter than critical, Geotech nique, Vol.13, pp. 211 240, 1963.

18）勝山潤一・西海健二・軽部大蔵：土木学会第 42 回年次学 術講演会, III, pp. 190〜191, Sep., 1987.

19）向後雄二：不飽和土の力学的挙動に対する弾塑性論的解 釈之解析, 土質工学会「不飽和土の工学的性質研究の現 状シンポジウム」論文集, pp. 69〜78, Dec., 1987.

20）勝山潤一・丹羽尚人・軽部大蔵: 土木学会第 41 回年次学 術講演会, III, pp. 295 296, 1986.

21) Yong, R. N., Japp, R. D. and How, G. : Shear strength of partially saturated clays, Proc. 4 th ARC-SMFE, Vol. 1, pp. 183 187, July, 1971.

(1988.10.19・受付) 